\title{
港湾構造物を利用した藻場造成に関する調査 AN INVESTIGATION ON THE UTILIZATION OF PORT STRUCTURES FOR ARTIFICIAL FORMATION OF SEAWEED BED
}

\author{
小野文雄 ${ }^{1}$ ・谷口義憲 ${ }^{2} \cdot$ 森利春 $^{3}$ ・宮原祐二 ${ }^{2} \cdot$ 早川淳 ${ }^{4}$ 。山田和彦 ${ }^{5}$ \\ Fumio ONO,Yoshinori TANIGUCHI,Toshiharu MORI,Yuji MIYAHARA,Jun HAYAKAWA, \\ Kazuhiko YAMADA \\ ${ }^{1}$ 正会員 国土交通省中部地方整備局清水港湾工事事務所 所長（广424-0922 静岡県清水市日の出町 7 番 2 号） \\ ${ }^{2}$ 国土交通省中部地方整備局清水港湾工事事務所（广424-0922＼cjkstart静岡県清水市日の出町 7 番 2 号) \\ ${ }^{3}$ 国土交通省中部地方整備局清水港湾工事事務所御前崎港事務所 所長（广421-0601 静岡県榛原郡御前崎町御前崎 6170)

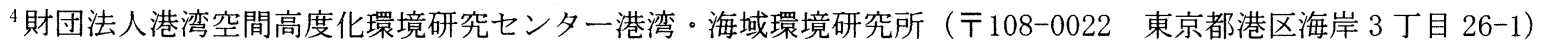 \\ ${ }^{5}$ 国土環境株式会社環境創造研究所（† 421-0212 静岡県志太郡大井川町利右衛門 1334-5)
}

\begin{abstract}
This investigation was aimed the creation of new growth grounds for seaweeds on the breakwater for the sake of the environmental-friendly utilization of port structures. The Port of Omaezaki, Shizuoka Prefecture, was selected as a survey field. The survey was carried out at the inside and outside of a seawall covered with wave-dissipating caissons and the slit caissons set up at the end of seawall. Seaweeds, including Ecklonia cava, ware confirmed to grow on artificial structures, in only a case of protection using net from herbivorous fishes, such as rabbitfish, Siganus fuscescens, and the slit caisssons, which can protect more easily from hervivorous fishes, are more useful ordinary wave-dissipating caissons. Many young frond, probably derived from mother thallus transplanted, ware found on the wave chamber floor of the slit caisson. The slit caisson is also useful as a place which supply zoospores.
\end{abstract}

Key Words : Slit caisson breakwater, breakwater wave chamber, seaweed bed, Eisenia arborea, Ecklonia cava.

1. 目的

御前崎港周辺海域では, 1989 年頃までアラメの近 縁種であるサリ゙ラメ（Eisenia arborea）とカジメ

(Ecklonia cava) が繁茂して藻場（海中林）を形成 していた. 当時の採藻漁業による漁獲量は 1 漁協当 たり年間 12〜14 レに達していたが, 1994 年には 0.9 トままで激減するなど, 藻場の深刻な衰退現象が生じ た ${ }^{1)}$. 現在, 藻場は一部の岩礁域にだけ残る状態 ${ }^{2)}$ と なり, 藻場の回復への取り組みが強く望まれるよう になった。

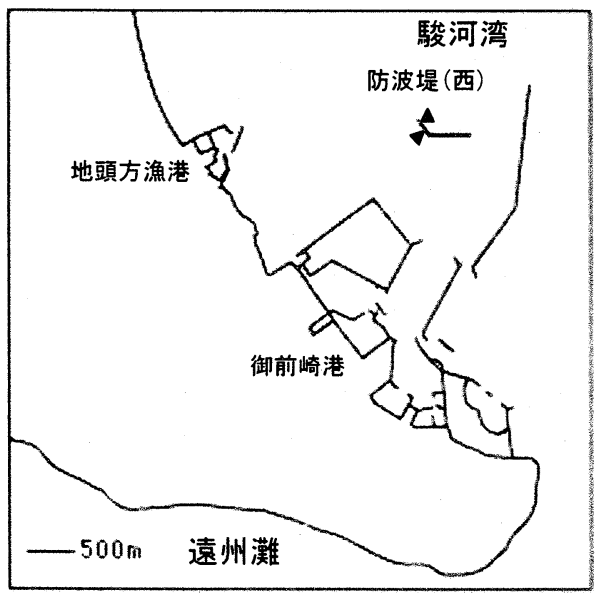

図-1 調査場所の概要。矢印は海藻移植場所を示す。
国土交通省中部地方整備局清水港湾工事事務所 では, 御前崎港防波堤 (西)で整備事業を進めている スリット式ケーソンの遊水部が, 上部コンクリート がないため太陽光が内部まで入射すること，外部と の海水交換が良好なこと，適度な波動が生じること などの特徴を有し, 海藻類の育成が可能な空間とし ての活用が期待できることに着目した. 本調查は港 湾構造物が海藻類をより効率的に着生させて藻場の 形成を図り, 周辺海域の環境保全, 漁業資源の育成に 貢献することを目的として行った。

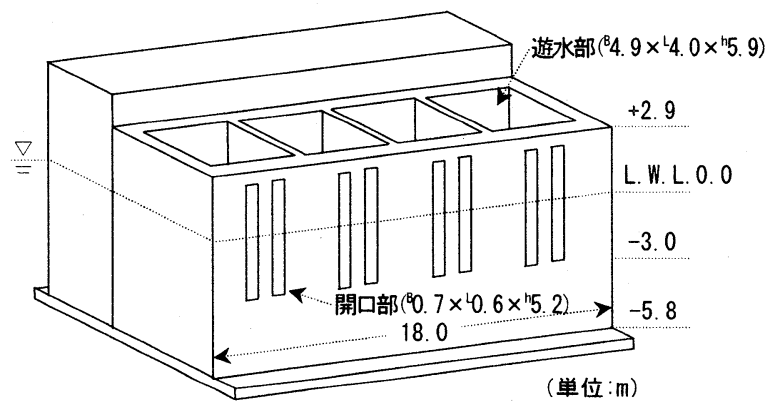

図-2 スリット式ケーソンの概要 


\section{2. 調査（試験）の内容及び方法}

\section{（1）食害対策試験}

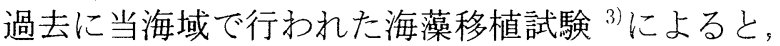
移植したカジメ類は生育が認められたものの, 夏季 に植食魚類（主にアイゴ Siganus fuscescens）によ る食害により消失したことが報告され，また近傍海 域で造成した藻場がアイゴの食害により消失した事 例 ${ }^{1)}$ が報告されている.これらの結果は, 当海域では 夏季を中心に植食魚類の食害を防止する必要がある ことを示しており,本調査においては食害対策試験 の方法や効果について検討した。

あらかじめ御前崎港防波堤 (西)の港内側底盤 部・港外側消波ブロック及びスリット式ケーソンの 遊水部にカジメを移植し, 食害対策を施した後, 食 害・残存状況を調查した。

港内側及び港外側については, 1999〜2000 年に母 藻移植（スポアバッグ法：成熟したカジメを網袋に 収めて, 基盤に固定する）之種苗移植（種采移植法： 成熟したカジメから遊走子を採苗後育苗し, 幼体の 着生する種系をコクリート釷を用いて基盤に固定す る）を行った。

スリット式ケーソン遊水部については, 2001 年に 母藻移植（カジメの仮根部をコンクリート製移植板 に接着し,基盤に固定する）と種苗移植を行った。

食害対策は 2000 年 8〜11月と 2001 年 6〜12月に 実施した。港内側では移植したカジメの周囲を漁網 (ポリブロピレン製 $37.5 \mathrm{~mm}$ 目) で井い, 港外側には 図-3 に示す 2 種類の人工海藻（ポリプロピレン製, 発泡ポリオレフィン製)をカジメの周囲に設置した。 スリット式ケーソン遊水部については開口部（1 室 当たり $0.4 \mathrm{~m} \times 5.22 \mathrm{~m} \times 2$ 箇所）に漁網（ポリプロピレ ン製 $37.5 \mathrm{~mm}$ 目）を設置し,藻体の食害状況を観察し た。

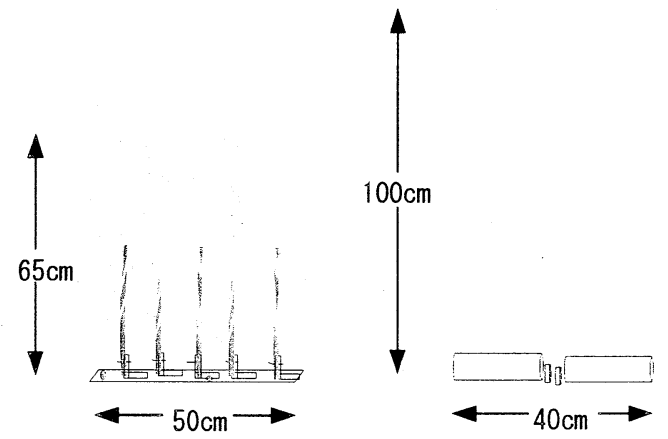

図-3 食害対策試験に用いた人工海藻の模式図 右：ポリプロピレン製, 左：発泡ポリオレフィン製

\section{（2）環境調査}

スリット式ケーソン遊水部が, 藻場の形成可能な 空間であるかを把握するために, 2001 年 3 月から 2002 年 2 月にかけて, 防波堤 (西)の港内側・港外側
及びスリット式ケーソン遊水部において,カジメの 生育に関係の深いと考えられる項目（水温。塩分・ 光量子量。流向流速）について測定を行った。なお， 水温・塩分はS T D (アレック電子製 AST-1000M） を, 光量子量は LI-192SA/B (盟和商事製) を, 流向流 速は ACM-200PC（アレック電子製）を用いて測定し た。また, 2001 年 3 月と 9 月にはスリット式ケーソン 遊水部の底面上に光量子計 (MDS-L, アレック電子製) を設置し,30日間の連続測定を行った。

\section{3. 結果}

\section{（1）食害対策試験}

\section{a）人工海藻設置区}

2 種類の人工海藻設置区とも, 試験開始後 1 週間で 平均藻長が $54.8 \mathrm{~cm}$ から $19.0 \mathrm{~cm} 、 52.2 \mathrm{~cm}$ から 26.2 $\mathrm{cm}$ 一減少し, 茥部と仮根部を残し中央葉がほぼ消 失した状態となっていた。試験開始から 1 力月後に は平均藻長は $5.6 \mathrm{~cm}, 8.0 \mathrm{~cm}$ となり, 仮根部と茎部を わずかに残すだけとなり,試験開始 2 力月後には仮 根部のみとなった（図-4）。

藻体の周囲に何も設置しなかった対照区では, 1 週間後には仮根部と茎部をわずかに残した状態とな っており, 対照区と比較すると, 食害の進行を遅らせ る効果はみられたが, 食害を防止する効果はなかっ た。

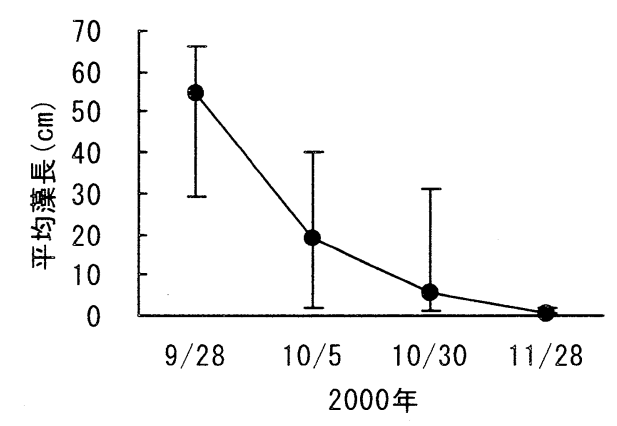

発泡ポリオレフィン製人工海藻

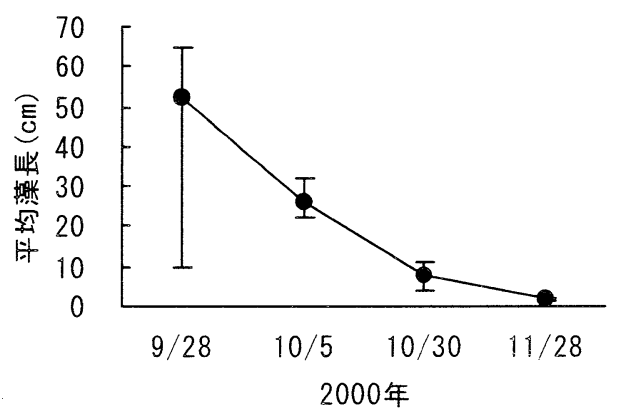

図-4人工海藻設置区におけるカジメ藻長の変化 


\section{b）漁網設置区一防波堤 (西) 港内側}

漁網設置区では, 試験開始後 1 力月で平均藻長が $50.0 \mathrm{~cm}$ から $44.7 \mathrm{~cm}$ とわずかに減少したが,試験開始 2 力月後には $51.1 \mathrm{~cm}$ となった（図-5）.

2000 年 11 月に漁網を撤収した以降は, 若干の食害 が生じていたが, 藻体は生残し, 生長点より新たに葉 状部が伸長する個体が認められた。

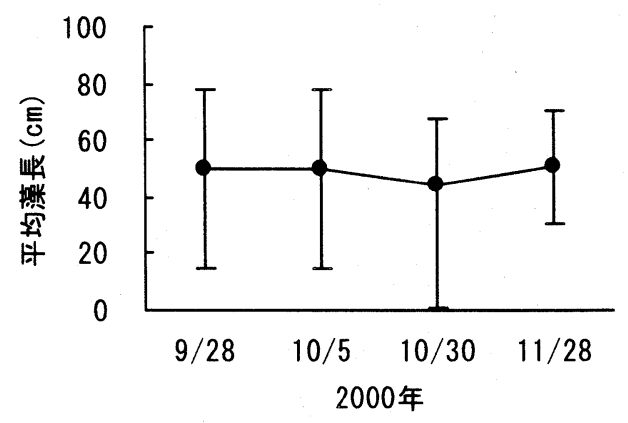

図-5 漁網設置区におけるカジメ藻長の変化

さらに, 2001 年 3 月には幼体が発芽し, 母藻移植に 用いた 5 枚の移植板（約 $0.1 \mathrm{~m}^{2} /$ 枚）上に $47 \sim 220$ 個体（藻長：1〜27 cm）が着生していた。母藻移植時 には, 遊走子が到達する範囲に天然のカジメの分布 はみられず, 幼体は移植に用いた藻体を母藻として 発芽したと判断された。

人工海藻設置区や対照区で藻体に損傷を受けた 大部分の個体の茎部に, 魚類による採食の痕跡が残 されたこと, 周辺で体長 10〜25 cmのアイゴが多数観 察されていることから，損傷はアイゴによる食害と 推定した.

\section{種苗移植後のカジメの藻長}

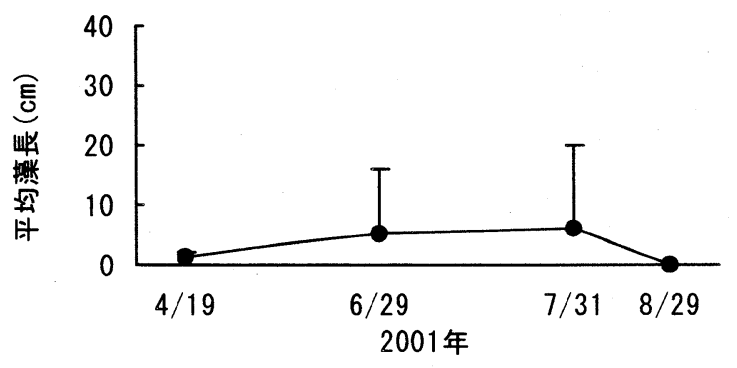

母藻移植後のカジメの藻長

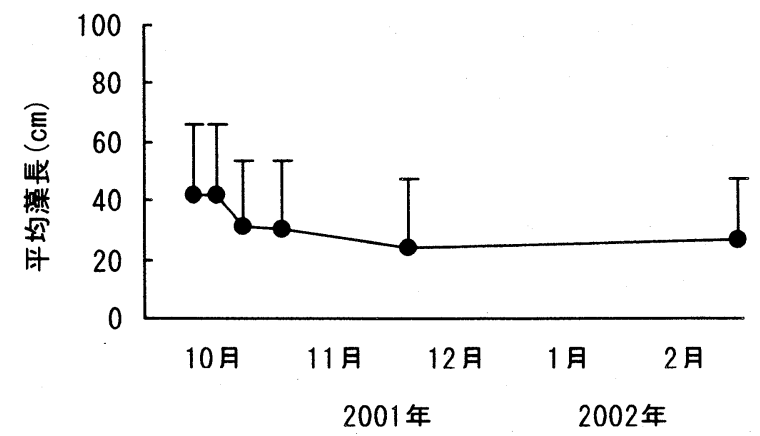

図-6 スリット式ケーソン遊水部におけるカジメ藻長の 変化

\section{c）漁網設置区ースリット式ケーソン開ロ部}

2001 年 6 月から 11 月までスリット式ケーソンの 開口部へ漁網を設置し,食害対策試験を行った。 しか

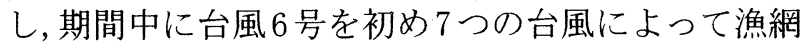
が損傷を受け, その都度修復を行ったが, 修復までの 間に食植魚類による食害が生じた。

種苗移植したカジメの平均藻長は, 食害対策試験 開始時の 6 月に $5.3 \mathrm{~cm}$ あり, 1 力月後には $6.3 \mathrm{~cm}$ (最 大藻長： $20 \mathrm{~cm} ）$ と生長を続けたが, 8 月上〜中旬に襲 来した台風の波浪と漁網が損傷を受けた際に生じた 食害により消失した（図-6 上）.

母藻移植したカジメの平均藻長は, 移植時に 41.9 $\mathrm{cm}$ あったが、11月の食害防止試験終了時には主に漁 網損傷時に生じた食害により $24.4 \mathrm{~cm}$ に減少した。そ の後試験終了時の 2002 年 2 月には, 食害を受けるこ ともなく平均藻長は $27.2 \mathrm{~cm}$ (最大藻長 : $47.0 \mathrm{~cm}$ ) とわずかながら生長していた（図一下）。

なお, 2 月には幼体が発芽し, 遊水部 1 室当たり 49 $\sim 370$ 個体 (平均藻長 : $2.0 \sim 4.5 \mathrm{~cm}$ ) が観察された。 母藻移植時には, 遊走子が到達する範囲に天然の力 ジメの分布はみられず,幼体は移植したカジメを母 藻として発芽したものと判断された。

\section{（2）環境調査}

a) 水温・塩分

スリット式ケーソン遊水部の表層での水温は 12.2 (2 月) $\sim 25.8^{\circ} \mathrm{C}$ (7 月) で, 防波堤 (西)の港内 側 $\left(12.6 \sim 26.3^{\circ} \mathrm{C}\right)$ や港外側 $\left(12.3 \sim 26.4^{\circ} \mathrm{C}\right)$ と比 べてほとんど差はなかった。

塩分は 32.9 (9 月） 34.4（3・6 月）で, 水温と 同様に防波堤 (西)の港内側 (32.8 34.4) や港外側 （32.9〜34.4）と比べて差はなかった（図-7）。

\section{b) 光量子}

スリット式ケーソン遊水部の底面上 $0.5 \mathrm{~m}$ での光 量子量は 20 (9 月) $\sim 482 \mu \mathrm{E} / \mathrm{m}^{2} / \mathrm{s}$ (7 月) であり, 海面直下を 100 とした時の相対光量は $7.8 \sim 44.5 \%$ であった. 遊水部底面上 $0.5 \mathrm{~m}$ 層は, 平均すると水深 約 $3 \mathrm{~m}$ に相当し, 防波堤 (西)の港内・港外側の水深 $5 \mathrm{~m}$ 層の值と一律に比較できないが, 港内側での值 (58 $\sim 338 \mu \mathrm{E} / \mathrm{m}^{2} / \mathrm{s}, 16.2 \sim 33.2 \%$ ） や港外側（25〜230 $\mu \mathrm{E} / \mathrm{m}^{2} / \mathrm{s}, 14.5 \sim 38.6 \%$ ） と比べて大きな差はみら れなかった（図一）。

2001 年 3 月にスリット式ケーソン遊水部の底面上 で行った光量子の連続測定結果によると, 日積算光 量子量は $0.3 \sim 1.4 \mathrm{E} / \mathrm{m}^{2} /$ day (平均 $0.7 \mathrm{E} / \mathrm{m}^{2} /$ day) で, 9 月の結果では $0.1 \sim 5.8 \mathrm{E} / \mathrm{m}^{2} /$ day (平均 $2.0 \mathrm{E} / \mathrm{m}^{2} /$ day) であった。 

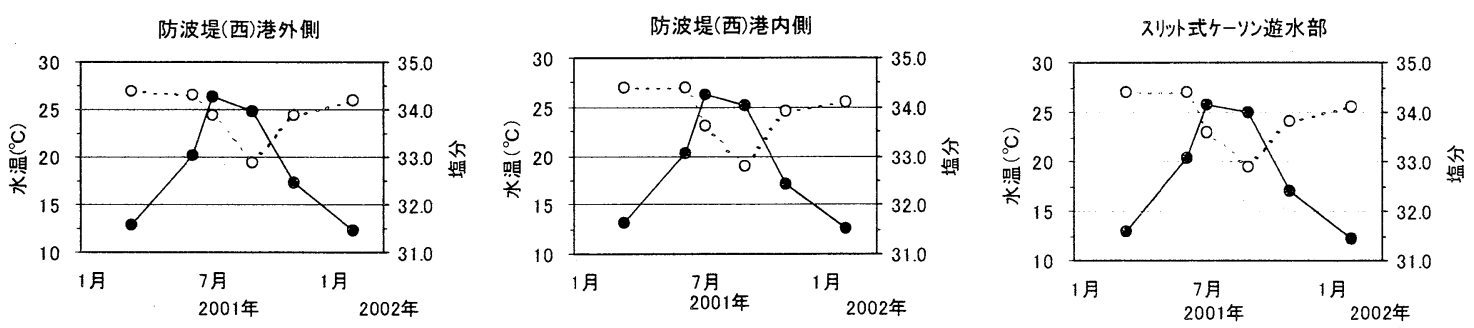

図-7 水温・塩分の季節的変化

は水温, ○は塩分を示す.
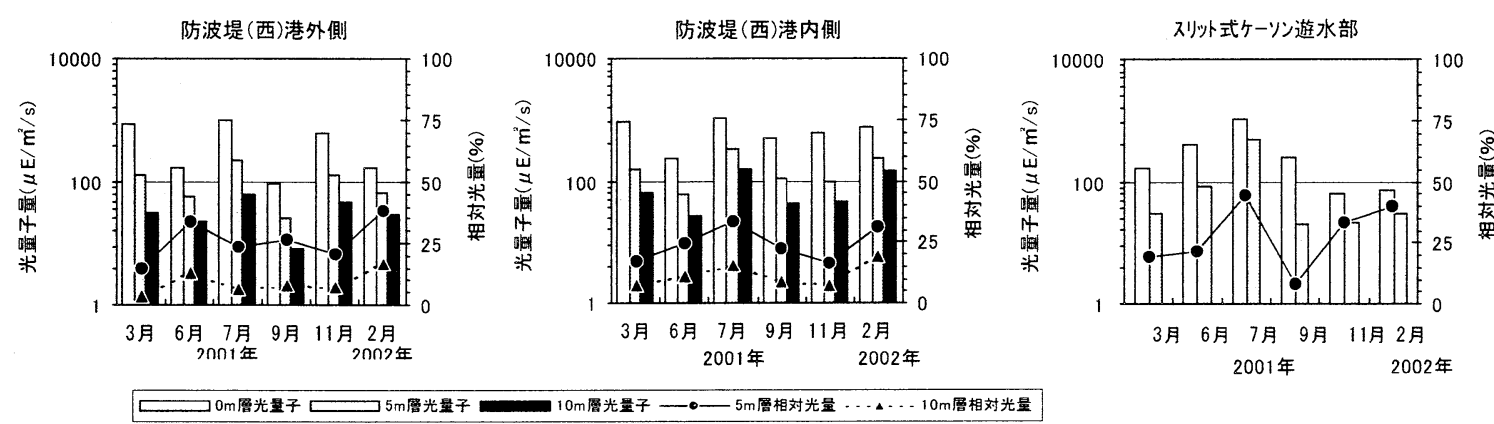

図-8 光量子量 (相対光量) の季節的変化. スリット式ケーソン遊水部の值 $\square$ はL.W. L. $-2.5 \mathrm{~m}$ での值を示す。

表-1 スリット式ケーソン遊水部の流速（底面上 $0.5 \mathrm{~m}$ )

\begin{tabular}{clcccc}
\hline & \multicolumn{1}{c}{ 測定場所 } & 開口部外側 & 開 П部内側 & 中央部 & 奥隅部 \\
\hline 2001 年 3 月 & 流速範囲 $(\mathrm{cm} / \mathrm{s})$ & $11 \sim 81$ & $8 \sim 73$ & $13 \sim 37$ & $1 \sim 22$ \\
(中潮時) & 平均流速 $(\mathrm{l})$ & 21 & 32 & 21 & 11 \\
\hline 2001 年 6 月 & 流速範囲 $(\mathrm{cm} / \mathrm{s})$ & $7 \sim 11$ & $3 \sim 10$ & $1 \sim 6$ & $<1 \sim 2$ \\
(小潮時) & 平均流速 $(\mathrm{l})$ & 9 & 6 & 3 & $<1$ \\
\hline
\end{tabular}
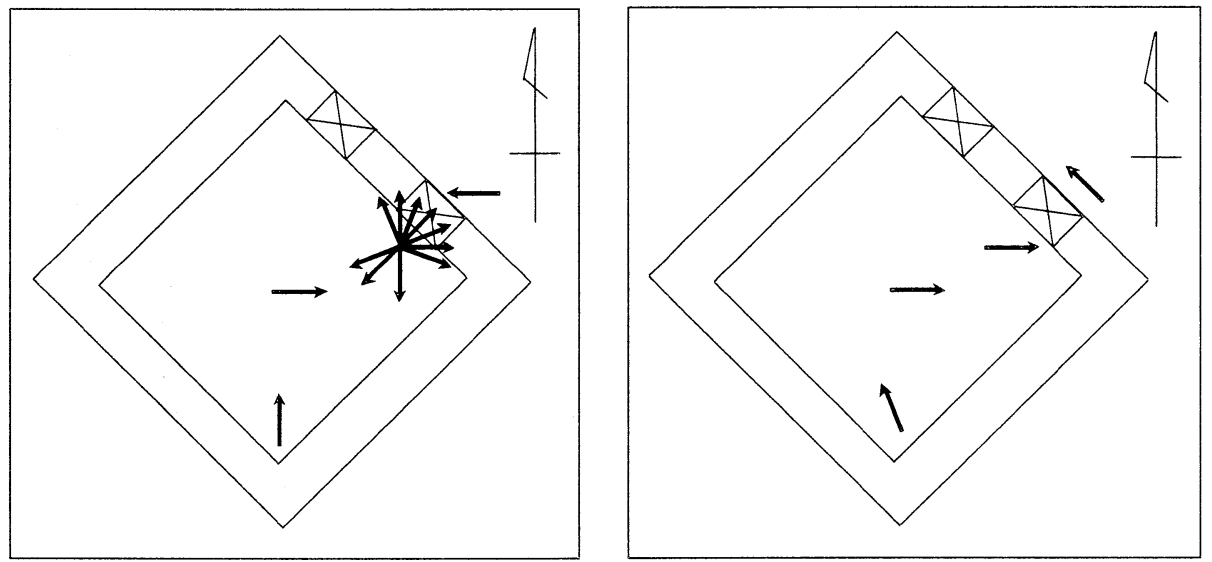

図-9 スリット式ケーソン遊水部の底面上 $0.5 \mathrm{~m} （$ L.W. L. $-2.5 \mathrm{~m} ）$ での流向

右 : 流速の最大時 (2001 年 3 月), 左 : 最小時 (2001 年 6 月), 10 回の測定で最も頻度の 高かった方向を示す。

\section{c）流向流速}

遊水部におけるカジメの生育水深である底面 上 $0.5 \mathrm{~m}$ 層（L.W.L. $-2.5 \mathrm{~m}$ ）で流向流速を測定した 結果, 平均流速は 1 末満〜 $32 \mathrm{~cm} / \mathrm{s}$ の範囲にあった

（表-1）。場所による流速の差をみると，ほとんど の測定時で開口部内側 $>$ 開口部外側 $>$ 中央部 $>$ 奥
隅部の順となっていた。

また、遊水部の中央（底面上 $0.5 \mathrm{~m}$ ）では開口部 へ, 奥隅部では中央入向から流れが生じる傾向が みられた（図一）。 


\section{4. 考察}

食植魚類に対する食害対策試験の結果, 最も効 果が高かったのは漁網を用いた方法であり, 藻体 の周囲あるいはスリット式ケーソンの開口部に漁 網を設置し, 食植魚類が藻体へ接近することを完 全に遮断する方法である。藻体を遮蔽して食植魚 類の接近を阻む人工海藻設置では, 上部が開放空 間であるため, 上部からの食害を防止することが できなかったものと考えられる.

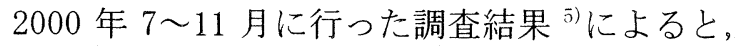
防波堤 (西)の周辺では 11 月を除いていずれもア イゴが観察され, 10 月には約 200 個体（体長 10〜 $20 \mathrm{~cm}$ ）が群れをなして遊泳するのが観察されてい る.さらに, 7 9 月には体長約 $30 \mathrm{~cm}$ の大型のアイ ゴがカジメを採食する様子も観察されている.ま た, 近傍海域に造成されたカジメ藻場が, 1998 年 と 1999 年の夏から秋にアイゴの食害により消失 したという報告 ${ }^{4)}$ みられる。

アイゴについては, 宮崎県日向灘北部熊野江地 先や門川地先でクロメ (Ecklonia kurome) 藻場が その食害により消失したこと ${ }^{6)}$ や和歌山県加太地 先でも多数のアイゴの目撃例とカジメ藻場への食 害が報告》されるなど,アイゴの食害が天然群落 の衰退要因あるいは回復制限要因となっており, 藻場造成の場でも阻害要因となっている.

御前崎港において港湾構造物を活用して藻場 造成を図る場合, 夏場を中心にアイゴの食害から 藻体を保護することが重要な課題である. 2000 年 に防波堤 (西)で行った漁網による食害防止対策

（移植したカジメの周囲の一面は防波堤を利用し， 残り三面を海底から海面まで漁網で囲む) では約 30 個体のカジメ（移植板 4 枚）を保護するために, 長さ $40 \mathrm{~m} \times$ 高さ $10 \mathrm{~m}$ の漁網を使用し, 規模として大 きなものとなっている.また, 波浪の強い港外側で 漁網を設置・維持することは非常に困難である。

一方, スリット式ケーソンの開口部に漁網を設 置して食害対策を施す方法では, 1 室 (試験では平 均 5 個体のカジメ) 当たり 2 箇所ある開口部（63 $\mathrm{cm} \times 522 \mathrm{~cm})$ に設置するだけでよいことから, 防波 堤 (西)の港外側で用いた方法と比べてより簡便な 方法であるといえる。

スリット式ケーソン遊水部内の環境条件につ いては, 水温・塩分, 光量子量など遊水部外と大き な差はない。

これらの值をカジメの生育環境要因から検討 寸ると, 成体の好適水温は $10 \sim 15^{\circ} \mathrm{C}$, 配偶体成熟 の限界は $10 \sim 25^{\circ} \mathrm{C}^{8)}$ とされており, スリット式ケ 一ソン遊水部内 $\left(12.2 \sim 25.8^{\circ} \mathrm{C}\right)$ では, 高水温時に 成体の好適水温を上回る懸念があるが, カジメの 生育する海域の夏季の水温は $23 \sim 27^{\circ} \mathrm{C}^{9)}$ とされる ことから, 遊水部ではカジメが生育できる範囲の
水温にあると判断される。塩分については, 適塩分 域は $32.0 \sim 34.8^{10)}$ とされ, 遊水部（32.9〜34.4） ではこの範囲にある。

配偶体の生長は $3,000 \sim 10,0001 u x$ で良く, 幼体 の生育限界は 90〜60, 0001ux ${ }^{8)}$ とされている。この 值を近似的な関係式 $\left.{ }^{11}\right)\left(5 \mu \mathrm{E} / \mathrm{m}^{2} / \mathrm{s} \neq 2501 \mathrm{ux}\right)$ で 換算すると, 前者が $60 \sim 200 \mu \mathrm{E} / \mathrm{m}^{2} / \mathrm{s}$, 後者が 2 $1,200 \mu \mathrm{E} / \mathrm{m}^{2} / \mathrm{s}$ となり, 遊水部 (12 757 $\mu \mathrm{E} / \mathrm{m}^{2} / \mathrm{s}$, 相対光量 : 7.8〜 44. 5\%) では最低時に配偶体の生 育に良いとされる範囲を下回るが, 幼体の生育範 囲には入っている.また, 3 月と 9 月に行った連続 測定結果では, 日積算光量の平均值がそれぞれ $0.7,2.0 \mathrm{E} / \mathrm{m}^{2} /$ day であり, 静岡県下田市鍋田湾で のカジメの日補償積算光量 $\left(3\right.$ 月 : $0.8 \mathrm{E} / \mathrm{m}^{2} / \mathrm{day}, 9$ 月： $\left.1.0 \mathrm{E} / \mathrm{m}^{2} / \mathrm{day}\right)^{12)}$ と比べると, 3 月はわずかに 下回るが, 9 月には大きく上回っている.さらに, カジメ幼体が生育する場所の相対光量は海面光量 の $0.5 \sim 1.0 \%$ であるという報告 ${ }^{13}$ があり,こうい った状況を併せると, 遊水部はカジメの生育が可 能な光環境にあると判断される.

造成されたカジメ藻場の平均流速は $8 \mathrm{~cm} / \mathrm{s}$ と推 定 ${ }^{14)}$ され, 実験 ${ }^{15}$ によるとカジメ遊走子の着生は $1.5 \mathrm{~cm} / \mathrm{s}$ で最大となり, $15 \mathrm{~cm} / \mathrm{s}$ 以上ではほとんど 着生できない. 遊水部内の平均流速 $(1 \mathrm{~cm} / \mathrm{s}$ 末満〜 $32 \mathrm{~cm} / \mathrm{s})$ はカジメの遊走子着生や生長に良好とさ れる範囲を上回る場合があるが，一時的な状態で あると考えられる。

以上のような状況から,スリット式ケーソンの 遊水部内ではカジメの生長全期にわたって, 生育 が可能な環境にあると考えられる。また。遊水部内 に移植したカジメが新たな側葉を形成するなど生 育を続けたほか, 前述のように移植したカジメを 母藻として幼体の出現がみられるなど, 遊水部内 での生育, 再生産が可能であることが確認されて いる.

したがって, 御前崎港防波堤 (西)において港湾 構造物を藻場造成のために活用することは十分可 能であり,スリット式ケーソンの遊水部内で形成

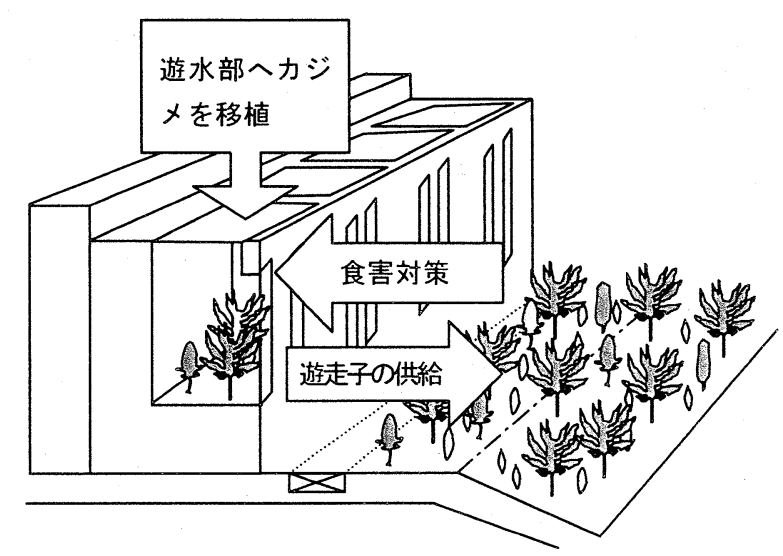

図-10 御前崎港における港湾構造物を利用した藻場造 成のイメージ 
された藻場が防波堤周辺へ遊走子を供給する核と しての役割を担うことが期待される（図-10）.

謝辞: 調查結果の取りまとめ, 藻場造成方法の検討 を行うにあたり,ご指導を頂いた御前崎港藻場造 成検討会 (座長: 有賀祐勝 東京水産大学名誉教授) の方々に厚くお礼申し上げます。

\section{参考文献}

1）運輸省第五港湾建設局清水港工事事務所・新日 本気象海洋株式会社: 平成 7 年度御前崎港海生 生物調查委託報告書, 1996 .

2）長谷川雅俊ほか：サガラメ群落の面積測定,平 成 9 年度静岡県水産試験場事業報告 書, p. 109, 1998.

3）運輸省第五港湾建設局清水港湾工事事務所・新 日本気象海洋株式会社: 平成 9 年度御前崎港海 生生物調查報告書, 1998 。

4）増田博幸ほか: 藻食性魚類アイゴの食害による造成 藻場の衰退, 水産工学, 37 (2), pp. 135-142, 2000.

5）国土交通省中部地方整備局清水港湾工事事務 所・港湾空間高度化環境研究センター: 平成 12 度御前崎港海生生物調査報告書, 2001 .

6) 清水博ほか：日向灘沿岸におけるクロメ場の立 地環境条件について, 宮崎県水産試験場事業報 告, 7, pp. 29-41, 1999.

7）山内信: 太平洋沿岸で発生した藻場の衰退現象, 和歌山県水試だより, 198, pp. 7-10. 1999.

8) 沿岸漁業整備開発事業施設設計指針編集委員 会：沿岸漁場整備開発事業施設設計指針（平成 4 年度版）, 全国沿岸漁業振興開発協会, 東 京, 1993.

9) 須藤俊造 : 海藻・海草相とその環境条件をより詰 めて求める試み, 藻類, 40, pp. 289-305, 1992.

10）漁場環境影響評価書検討専門委員会：環境が 海藻類に及ぼす影響を判断するための『判断 基準』と『事例』, 日本水産資源保護協会, 東 京, pp. 61-71, 1992.

11) 徳田廣: 海藻の生育環境, 海藻資源養殖 学, pp. 15-33, 緑書房, 1987.

12）倉島彰ほか: 褐藻アラメ・カジメの生理特性, 藻類, 44, pp. 87-94, 1996.

13）前川行幸ほか：褐藻アラメ及びカジメ幼体の 光要因からみた生育限界の比較, 藻類 36, pp. 166-174, 1998.

14）金杉佐一ほか：磯焼け地域におけるアラメ。 カジメの天然群落の拡大に関する研究, 昭和 $56 \sim 58$ 年度指定調查研究総合助成事業報告 書, pp. 1-20, 1984.

15）柳瀬良介ほか: カジメ群落拡大に関する研究, 昭和 57 年度指定調査研究総合助成事業報告 書, pp. 1-14, 1983. 